\title{
MODAL MANUSIA PADA INDUSTRI TENUN SONGKET SAMBAS DI KABUPATEN SAMBAS KALIMANTAN BARAT (POTRET DAN KARAKTERISTIKNYA)
}

\author{
JAMALIAH \\ Staf Pengajar Fakultas Ekonomi dan Bisnis Universitas Tanjungpura Pontianak
}

\begin{abstract}
ABSTRAK
One attempt to boost economic growth is doing construction industry sector. Industrial development is intended to strengthen the national economic structure, improve the durability of the economy, expand employment and business opportunities, and at the same time promoting the growth of other development sectors.

Interest is expected to be achieved through the efforts of improvement include improving the quality of human resources, provide adequate facilities and infrastructure, regulated bureaucracy and other policies that encourage the achievement of the industrial sector.

The purpose of this study are as follows: 1 .To provide an overview of the situation and the social, economic and demografipekerja on household industry weaving in Sambas district. 2. To provide an overview of the historical development of domestic industries of weaving and characteristics of the variables in the form, output and wages of workers, labor resources, working capital, and product pricing, marketing, payment or the income level of workers, the range of products and others.

This study uses quantitative and qualitative analysis techniques. Quantitative analysis with descriptive analysis, data obtained through the field and that has been collected and analyzed as it is without intending to make conclusions that are generally applicable. Behavioral variables studied, then the data are analyzed quantitatively in terms of percentage in order to obtain an overall picture. The data will also be analyzed qualitatively through qualitative analysis techniques through interpretation.
\end{abstract}

The findings in this study indicate that the Sambas weaving industry is growing although not yet optimal. Productivity is relatively low (1bulan / piece)

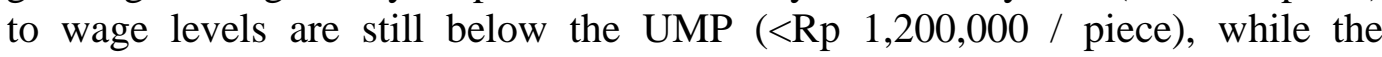
working capital is relatively large and the price depends on the quality of the variation between $\mathrm{Rp} 600,000$ - Rp 7,500,000, as well as orders mostly focused on local or domestic market

Keyword: Household Industry, Weaving, Human Capital

\section{PENDAHULUAN}

\section{Latar Belakang}

Salah satu usaha untuk meningkatkan pertumbuhan ekonomi adalah melakukan pembangunan sektor industri. Pembangunan industri ditujukan untuk memperkokoh struktur perekonomian nasional, meningkatkan daya tahan perekonomian, memperluas lapangan pekerjaan dan kesempatan berusaha, serta sekaligus mendorong berkembangnya kegiatan berbagai sektor pembangunan lainnya. Idris Fahmi (2010) mengemukakan bahwa tujuan pembangunan industri, 
baik jangka menengah maupun jangka panjang adalah untuk mengataai permasalahan yaitu ;

1. Meningkatkan penyerapan tenaga kerja di sektor industri,

2. Meningkatkan ekspor Indonesia dan pemberdayaan pasar dalam negeri,

3. Memberikan sumbangan pertumbuhan yang berarti bagi perekonomian,

4. Mendukung perkembangan sektor infrastruktur,

5. Meningkatkan kemampuan teknologi,

6. Meningkatkan pendalaman strutur industri dan diversifikasi produk dan

7. Meningkatkan penyebaran industri.

Tujuan tersebut diharapkan dapat dicapai melalui upaya-upaya perbaikan antara lain dengan meningkatkan kualitas sumber daya manusia, menyediakan sarana dan prasarana yang memadai, diregulasi birokasi dan kebijakan-kebijakan lain yang mendorong pencapaian sektor industri tersebut

Dalam pada itu, upaya pengembangan sektor industri rumah tangga tenun dapat dilakukan dengan berbagai model antara lain yaitu dengan model human capital. Tantangan perusahaan- perusahaan masa kini harus mampu merespon pergeseran dari yg terfokus pada masalah industri ekonomi kearah knowledge ekonomi. Pergeserani ini meliputi seluruh aspek manajemen yaitu efisiensi operasi, marketing, struktur organisasi yang akan memberikan keuntungan bisnis yang lebih tinggi, secara kualitatif kontribusi human capital dipusatkan pada nilai dan tindakan manusia (Drucker).

Secara umum dapat dilihat bahwa seorang pekerja sebagai salah satu input memiliki persamaan dan perbedaan dengan input lainnya. Persamaannya adalah sama-sama mempunyai keterbatasan sedangkan perbedaannya karena pekerja tidak dapat dipisahkan dari pemiliknya artinya dia sebagai input sekaligus sebagai pemilik faktor produksi tersebut, pekerja mempunyai dinamika dapat mengubah dirinya menjadi lebih baik, dapat berbagi dengan pihak lain serta mempunyai kemampuan yang nilainya tidak berkurang meskipun disebarkan kepada orang lain. Keunikan dari manusia inilah yang menempatkan mereka sebagai faktor produksi terpenting dalam proses produksi.

Oleh karena pekerja berperan penting dalam proses produksi, maka dibutuhkan pekerja yang berkualitas dan konsep human capital adalah untuk meningkatkan kualitas pekerja. Human capital juga dapat mengarahkan pekerja pada penciptaan spesialisasi sehingga dapat meningkatkan produktivitas. Telah banyak dibuktikan bahwa human capital atau modal manusia merupakan sebuah sistem yang dapat memperbaiki kinerja karyawan, meningkatkan kompetensi sehingga mampu menghasilkan barang dan jasa sesuai dengan kebutuhan konsumen yang lebih baik, halini pada gilirannya akan meningkatkan pendapatan dan kesejahteraan pekerja. Human capital merupakan kombinasi dari pengetahuan,keterampilan, inovasi dan kemampuan seseorang untuk menjalankan tugasnya sehingga dapat menciptakan suatu nilai untuk mencapai tujuan. Pembentukan nilai tambah yang dikontribusikan oleh modal manusia dalam menjalankan tugas dan pekerjaannya akan memberikan sustainable revenue dimasa akan datang bagi suatu organisasi (Edwinson dan Malone, 1997 ; Stockley, 2003 dalam Ardinia (2015)).

Kabupaten Sambas adalah merupakan salah satu daerah di Kalimantan Barat yang berbatasan dengan Malaysia, disamping beberapa kabupaten lainnya yang juga berbatasan dengan Malaysia, akan tetapi diantara daerah lainnya maka 
Sambas memiliki IPM yang paling rendah $66,81 \%$ pada tahun 2013, Produk Domestik Regional Bruto (PDRB) Kabupaten Sambas Rp 118.623.256,20. Lapangan pekerjaan sebagian besar adalah sektor pertanian, selain itu salah satu pekerjaan yang digeluti masyarakat sambas terutama yang wanita adalah industri rumah tangga tenun yang merupakan salah satu budaya masyarakatnya secara turun temurun. Industri tenun ini awalnya dikerjakan di rumah-rumah tetapi sekarang sebagian sudah melalui pembinaan dan berada pada sentra-sentra, kantong-kantong penduduk pada daerah - daerah tertentu. Produk yang dihasilkan antara lain kain songket, bahan baju, selendang, sajadah, taplak meja, sarung kursi, kopiah, shal, tempat tissu dan lain-lain. Walaupun sudah ada pembinaan dan verifikasi produk tetapi sebagian besar masih mengerjakan secara tradisional dan berbasis budaya sehingga hasil yang diperoleh belum berkembang sebagaimana yang diharapkan dan belum mampu bersaing pada tingkat nasional dan internasional.

Kondisi tersebut menunjukkan bahwa permasalahan pada industri songket tenun Sambas merupakan salah satu fenomena penting yang harus diperhatikan dan dikembangkan karena tidak hanya menyangkut persoalan budaya dan kebiasaan tetapi juga menyangkut lapangan pekerjaan dan persoalan ekonomi.

Oleh karena itu perlu dikaji lebih lanjut tentang kondisi pada industry tenun sambas tersebut yang meliputi kondisi sosial, demografi, output, daya serap pekerja, tingkat upah, ragam produk dan lain - lain.

\section{Tujuan Penelitian}

Adapun tujuan penelitian ini adalah sebagai berikut :

1. Untuk memberikan gambaran tentang situasi dan kondisi sosial, ekonomi dan demografipekerja pada industri rumah tangga tenun di kabupaten sambas.

2. Untuk memberikan gambaran terhadap perkembangan dan sejarah industri rumah tangga tenun dan karakteristik variabel-variabelnya berupa, output dan upah pekerja, sumber pekerja, modal kerja, dan harga produk, pemasaran, tingkat upah atau penghasilan pekerja, ragam produk dan lainlain.

\section{Manfaat Penelitian}

Penelitian ini diharapkan memberikan manfaat praktis yaitu sebagai masukan bagi pemerintah provinsi dan pemerintah kabupaten sambas dalam merumuskan dan menentukan kebijakan yang berkaitan dengan pengembangan industri rumah tangga tenun di kabupaten sambas, juga diharapkan bermanfaat bagi pelaku bisnis dan pekerja. Dalam pada itu, hasil penelitian ini juga diharapkan bermanfaat bagi peneliti yang akan melanjutkan penelitian ini.

\section{TINJAUAN PUSTAKA \\ Landasan Teori}

Dilihat dari penyerapan tenaga kerja, sektor industri terus mengalami peningkatan walaupun tidak sebesar penyerapan di sektor pertanian. Proses industrialisasi yang terjadi melalui akumulasi modal dan penggunaan teknologi, telah mengubah secara mendasar struktur sektor manufaktur seperti komposisi produk-produk utama, keragaman barang-barang yang diproduksi, maupun kandungan teknologinya (Putra, 2008:7). 
Pembangunan industri dikembangkan secara bertahap dan terpadu melalui peningkatan keterkaitan antara industri dan antarsektor industri dengan sektor ekonomi lainnya, terutama dengan sektor ekonomi yang memasok bahan baku industri. Sinergisitas itu dilakukan melalui penciptaan iklim yang lebih merangsang bagi penanaman modal dan penyebaran pembangunan industri di berbagai daerah, terutama di kawasan timur Indonesia sesuai dengan potensi masing-masing dan sesuai dengan pola tata ruang nasional. Dalam rangka pemerataan kesempatan usaha serta demi terciptanya iklim usaha yang dapat memantapkan pertumbuhan industri nasional, maka perluasan usaha industri perlu diarahkan pada pemusatan kekuatan industri diberbagai daerah.

Bertolak dari kenyataan ini, industri kecil dan rumah tangga merupakan suatu alternatif untuk meningkatkan penyerapan tenaga kerja terutama di daerah daerah. Human capital memiliki kontribusi penting dalam pembangunan melalui pengembangan sumber daya manusia sehingga dapat mendorong peningkatan kesejahteraan, yang berarti mengurangi kemiskinan.

Menurut World Development Report (Bank Dunia ; 1990 dalam Nafziger : 1997), ada dua strategis untuk mengatasi kemiskinan yaitu mendorong pertumbuhan padat karya dan berinvestasi dalam modal manusia.

Oleh karen itu, pada dasarnya sektor industri khususnya industri kecil dan rumah tangga harus mendapat rempat sebagai prioritas pembangunan di Kalbar. Pembangunan industri rumah tangga tenun di Kabupaten Sambas dapat didekati dengan model human capital untuk pengembangan sumber daya manusia sehingga dapat meningakatkan nilai tambah produksi, produktivitas dan pada giliran selanjutnya akan meningkatkan kesejahteraan masyarakat melalui peningkatan upah. Hal itu tentu saja dapat membantu pemerintah daerah dalam mengejar pertumbuhan ekonomi yang tinggi, menurunkan angka pengangguran dan kemiskinan di Kabupaten Sambas.

\section{Teori Human Capital}

Human capital atau modal manusia sebagai sistem yang dirancang untuk memperbaiki kinerja karyawan dan menciptakan keunggulan kompetitif yang berkelanjutan Teori modal manusia menganggap bahwa keuntungan dalam suatu usaha akan mengalami perkembangan apabila usaha itu mampu menghasilkan barang atau jasa yang sesuai dengan kebutuhan konsumen dimasa sekarang dan di masa depan.. oleh karenanya suatu usaha harus dapat menjaga dan meningkatkan pelayanan dan yang selalu disesuaikan dengan dinamika kebutuhan konsuman atau masyarakat.

Menurut Edwinson dan Malone (1997) dalam Ardinia (2015), terdapat dua prinsip kunci dalam human capital yaitu:

1. Manusia merupakan aset yang memiliki nilai yang dapat ditingkatkan melalui investasi. Tujuan dari investasi ini adalah memaksimalkan nilai melalui manajemen resiko. Ketika nilainya meningkat, kapasitas organisasi dan nilai- nilainya akan meningkat dan menguntungkan stokeholder.

2. Kebijakan human capital dalam organisasi harus di sesuaikan dengan dukungan organisasi, yaitu visi, misi, tujuan dan strategi sebagai arahan yang telah dirancang untuk dapat di implementasikan dan dinilai oleh sebuah standar, bagaimana konsep human capital ini dapat membantu organisasi mencapai visi dan misi nya. 
Human capital merupakan kombinasi dari pengetahuan, keterampilan atau skill, inovasi dan kreativitas dan budaya kerja seseorang dalam menjalankan tugasnya sehingga dapat menciptakan suatu nilai untuk mencapai tujuan. Pembentukan nilai tambah yang dikontribusikan oleh human capital dalam melaksanakan pekerjaannya akan meningkatkan produktivitas dan akan memberikan penghasilan berkelanjutan dimasa yang akan datang bagi para pekerja. Hal semula juga dikemukakan oleh Desster (2011).

\section{Studi Pendahuluan}

Ada sejumlah penelitian yang bersinggungan dengan masalah ini. Pertama, penelitian Gabriel dkk (2013) tentang perencanaan strategi pengembangan industri rumah tangga gula kelapa studi kasus industry rumah tangga gula kelapa Desa Gledug Kecamatan Sanan Kulon Kabupaten Blitar. Temuan dalam studi ini menunjukkan bahwa gula kelapa merupakan salah satu produk sektor agro industri dengan potensi pengembangan yang baik. Potensi ini didukung dengan adanya prospek pangsa pasar lokal maupun pasar luar negeri yang baik. Tujuan dari penelitian ini ialah untuk memperoleh perumusan strategi yang dapat digunakan untuk memaksimalkan pemanfaatan potensi dalam upaya mengembangkan Industri Rumah Tangga (IRT) gula kelapa Desa Gledug. Dari hasil analisis SWOT diperoleh 9 alternatif strategi pengembangan yang dapat diterapkan. Dari hasil pembobotan metode Analytical Network Process (ANP), didapatkan bahwa strategi pembentukan ikatan kerjasama dengan lembaga pengembangan industri merupakan strategi pengembangan yang terbaik untuk diterapkan di IRT gula kelapa Desa Gledug.

Kedua, penelitian dari Rahmawati dan Amir (2003) dengan judul "Studi Potensi Industri Kecil di Desa Tertinggal Dalam Rangka Pemberdayaan Pengusaha Kecil di Kabupaten Banyumas1". Temuan dalam penelitian ini salah satunya adalah kendala human capital yang dihadapi dalam industri kecil antaranya : motivasi usaha rendah; pengetahuan dan ketrampilan tenaga kerja kurang memadai; permodalan \& aksesnya; peralatan/teknologi produksi mamual \& sederhana, tidak ada standarisasi produksi, produk, kemasan dan jangkauan pemasaran terbatas.

Ketiga, studi yang dilakukan Yusriansyah (2011) menyatakan bahwa Karakteristik pengusaha industri keripik tempe di Kota Malang secara umum memiliki jumlah pekerja 4-19, mempunyai aset industri tidak lebih dari 200 juta, serta omset tahunan yang tidak lebih dari satu miliar per tahunnya. 2) Keripik tempe menjadi produk unggulan di Kota Malang karena bahan yang mudah didapatkan dari usaha tempe masyarakat sekitar yang merupakan produk yang tidak tahan lama, agar tahan lama maka dibuatlah keripik tempe, keripik tempe mampu berkembang dari generasi ke generasi dengan inovasi berbagai aneka rasa, berdaya saing handal dengan produk yang berkualitas, memberikan peluang kerja bagi masyarakat lokal serta dipasarkan mulai dari kawasan regional, nasional, sampai internasional. 3) Produktivitas industri keripik tempe di Kota Malang tergolong tinggi, yaitu mencapai biaya operasional harian yang mereka butuhkan dalam sehari mencapai lebih dari 500 ribu, dan pendapatan per bulannya antara 10 juta hingga 20 juta.

\section{METODE PENELITIAN}




\section{Rancangan Penelitian}

Penelitian ini tergolong kedalam jenis penelitian deskriptif. Penelitian deskriptif adalah penelitian yang ingin menggambarkan karakteristik objek yang di teliti (Ruslan, 2006:12). Dalam penelitian ini akan dilengkapi dengan bagan penelitian sesuai dengan tahapan yang akan dilakukan, mulai dari lokasi pelaksanaan, kerangka pikir, analisis luaran serta indikator capaian secara terukur.

\section{Populasi Dan Sampel Penelitian.}

Lokasi penelitian adalah beberapa desa/ kecamatan di kabupaten sambas yaitu desa jagur, tumuk manggis, tanjung mekar, sumber harapan dan kecamatan sajad, daerah-daerah yang merupakan kantong-kantong/sentra-sentra industri rumah tangga tenun. Mengingat data besarnya populasi tidak tersedia dengan akurat, maka responden akan dipilih berdasarkan metode purposive, yaitu yang disesuaikan dengan tujuan penelitian.

\section{Teknik Pengumpulan Data}

Pengumpulan data akan dilakukan melalui penyebaran angket, wawancara, observasi secara langsung kepada responden dan pihak-pihak yang terkait. Disamping itu juga akan dilakukan melalui studi kepustakaan yaitu mempelajari laporan statistik, dokumen, koleksi buku untuk pengayaan analisis.

\section{Teknik Analisis Data.}

Penelitian ini menggunakan teknik analisis kuantitatif dan kualitatif. Analisis kuantitatif dilakukan dengan analisis deskriptif, data yang diperoleh melalui lapangan dan yang telah dikumpulkan dianalisis sebagaimana adanya tanpa bermaksud membuat kesimpulan yang berlaku umum. Prilaku variabel yang diteliti, selanjutnya data tersebut dianalisis secara kuantitatif dalam bentuk persentase guna diperoleh gambaran secara menyeluruh. Data tersebut juga akan di analisis secara kualitatif melalui teknik analisis kualitatif melaui interpretasi.

\section{HASIL DAN PEMBAHASAN}

\section{Kondisi Umum Kabupaten Sambas dan Industri Tenun Sambas}

Berdasarkan data Dinas Kependudukan dan Pencatatan Sipil Kabupaten Sambas per Agustus 2013 jumlah penduduk Kabupaten Sambas sebanyak 667.921 jiwa. Total penduduk laki-laki sebanyak 341.982 jiwa (51\%), sedangkan penduduk perempuan sebanyak 325.939 jiwa (49\%). Jumlah penduduk sambas lebih di dominasi penduduk dengan usia produktif di bandingkan penduduk usia tidak produktif ini bisa dilihat dari jumlah penduduk berdasarkan kelompok umur (BPS, 2013) :

Tabel 1. Jumlah Penduduk Berdasarkan Kelompok Umur Tahun 2013

\begin{tabular}{ccc}
\hline No & Kelompok Umur & Persen $(\%)$ \\
\hline 1 & $0-14$ tahun & 26 \\
2 & $15-64$ tahun & 66 \\
3 & 65 tahun ke atas & 8 \\
\hline
\end{tabular}

Sumber : BPS, 2013

Jumlah penduduk Kabupaten Sambas tahun 2013 menurut kelompok umur pada usia produktif yaitu 15-64 tahun terbesar yaitu sebanyak 66 persen dari jumlah penduduk Kabupaten Sambas. Jumlah penduduk pada kelompok umur 0-14 tahun sebanyak 26 persen dan sementara itu jumlah penduduk pada kelompok 65 tahun keatas sebanyak 8 persen . 
Keterkaitan kependudukan dan pembangunan telah menjadi isu menarik dalam proses pembangunan sosial ekonomi Indonesia dan daerah selama ini. Dinamika kependudukan mulai dari pertumbuhan penduduk, kuantitas penduduk, distribusi penduduk akan memberi implikasi timbal-balik terhadap berbagai bidang pembangunan. Beberapa waktu lalu, isu kependudukan menjadi semakin menarik disaat pembangunan nasional maupun pembangunan daerah dihadapkan pada peningkatan pengangguran, melebarnya kesenjangan sosial, membengkaknya angka kemiskinan, terbatasnya lahan pertanian hingga menyempitnya lapangan pekerjaan.

Menyiasati isu kependudukan di atas dapat dilakukan dengan menggerakan ekonomi kreatif yang pada akhirnya akan menjadi mesin penggerak ekonomi kreatif adalah industri kreatif. Industri kreatif sendiri sebenarnya merupakan istilah yang muncul lebih dulu dibanding ekonomi kreatif. Pergeseran paradigma pembangunan ekonomi saat ini mengarah kepada paradigmaa ekonomi kreatif yang mendorong lahirnya cara-cara baru dalam mendekati masalah pembangunan (Fontana; 2012). Dalam paradigma perekonomian kreatif, yang menjadi pusat perhatian adalah sosial dan lingkungan. Sedangkan dalam perekonomian model lama, ekonomi adalah pusat perhatian. Lingkungan dan social bahkan menjadi hamba ekonomi.

Sejumlah kota-kota besar dengan dimotori anak-anak muda, akhir-akhir ini menyambut datangnya wacana ekonomi kreatif. Ekonomi yang lebih mengedepankan kreativitas dan inovasi sebagai motor penggerak ekonomi. Banyak yang menyatakan ekonomi kreatif adalah ekonomi gelombang keempat, yang berorientasi pada kreativitas, budaya, serta warisan budaya, dan lingkungan. Pembagian gelombang itu sebenarnya kelanjutan dari teori Alvin Toffler, yang membagi peradaban ke dalam tiga gelombang, yaitu gelombang pertama adalah abad pertanian, gelombang kedua abad industri, dan gelombang ketiga abad informasi, serta gelombang keempat yang dinamakan dengan ekonomi kreatif.

Kabupaten Sambas terletak di ujung utara Kalbar, dan merupakan salah satu dari tiga kabupaten di Kalbar yang berbatasan langsung dengan Malaysia Timur ( Sarawak), selain Sanggau dan Kapuas Hulu. Tentu selain diuntungkan oleh faktor geografis tersebut, posisi itu juga menimbulkan kerawanan. Masuknya narkoba dari negara tetangga serta maraknya TKI/TKW ilegal dari Kab. Sambas ke Malaysia melalui 'jalan tikus' merupakan potensi ancaman yang harus diantisipasi sedini mungkin. Selain itu, masalah keterbelakangan dan kemiskinan masyarakat di wilayah perbatasan bukanlah hal baru, dan hal ini sering memicu terjadinya masalah sosial. Bahkan seringkali dijumpai, masyarakat di perbatasan tidak merasa bahwa mereka merupakan bagian dari Indonesia. Secara psikologis dan geografis, mereka memang lebih dekat dengan negara tetangga. Hal itu juga menimpa sebagian masyarakat Sambas, khususnya yang berdomisili di dekat perbatasan Malaysia, seperti di Kecamatan Sajingan dan Paloh.

Pemerintah Kab. Sambas sedang menggiatkan industri kreatif bercirikan kearifan lokal Melayu Sambas. Salah satu produk yang dapat diandalkan mereka adalah berupa kain tenun/ songket. Kain tenun Sambas bahkan dua kali mendapat penghargaan warisan budaya tak benda khas Kalbar dari UNESCO. Pertama pada tahun 2012 silam, dan yang kedua pada 2014. Tenun Sambas pun pernah mendapatkan penghargaan rekor Muri dengan ukuran terpanjang di Indonesia. Hal 
sejalan dengan Fontana (2012) tentang penggeseran paradigm pembangunan ekonomi saat ini yang mengarah kepada ekonomi kreatif.

Selain proses produksi yang terbilang sulit. Bahan baku untuk membuat kain juga menjadi masalah dalam proses produksi karena sulitnya untuk menemukan bahan baku dalam pembuatan kain songket. Benang semakin sulit diperoleh. Kalau pun ada, harganya cukup mahal. Dan yang semakin menjadi sulit adalah semakin berkurangnya tenaga penenun dan orang yang mau belajar menenun. Hal ini dikarenakan mereka banyak hijrah dan mencari pekerjaan lain di Malaysia. Dengan alasan yang cukup manusiawi yaitu penghasilan yang menurut penenun masih sangat rendah ini dapat dilihat dari rata - rata penghasilan penenun sebulannya hanya kurang lebih Rp 800.000,- s.d Rp 1.000.000,- dan hal tersebut lebih kecil dari Upah Minimum Kabupaten (UMK) yaitu sebesar Rp 1.400.000,-. Penghasilan dari menenun, tidak menghasilkan cukup uang. Sehingga banyak pengrajin di daerah ini, menjadi penenun di Brunei. Untuk mendapatkan penghasilan yang lebih menjanjikan dari segi pendapatan.

\section{Modal Kerja dan Harga Produk}

Hasil kerajinan tenun songket Sambas banyak di perdagangkan sejak tahun 1960-an hingga sekarang, dan pada awalnya jenis barang yang dibuat hanya sebatas kain dan selendang sebagai pakaian kaum wanita dan kain sabuk atau setengah tiang untuk pakaian lelaki. Seiring perkembangan waktu memasuki tahun 2000-an, hasil kerajinan tenun songket Sambas mengalami penambahan jenis produk seperti : kopiag (peci), baju muslim untuk kaum lelaki, atau baju kebaya dari tenunan untuk kaum wanitanya, sajadah, syal, kaligrafi atau gambar mesjid untuk hiasan dinding, dan banyak lagi pengembangan yang dilakukan.

Melihat besarnya potensi dari usaha kerajinan tenun songket Sambas, hingga sampai saat ini masih banyak masyarakat Sambas yang berprofesi sebagai pemilik sekaligus pengelola usaha kerajinan tenun songket Sambas. Dalam memulai usaha kerajinan tenun songket sebagai modal awal untuk membeli alat dan bahan dibutuhkan total biaya Rp 5.300.000. terdiri dari :

- Satu set alat perumahan tenun Rp 1.500.000,-

- Alat tarrauan (pemintal benang) Rp 300.000,-

- Alat menganek satu set Rp 500.000,-

- Bahan benang dan lainnya Rp 300.000,-

Adapun harga jual dari hasil kerajinan tenun songet tergantung pada jenis produk yang ditawarkan dan tergantung pula pada tingkat kerumitan motif yang dibuat. Semakin rumit tingkat kesulitan dalam membuat sebuah motif pada pengerjaan tenun songket maka akan mempengaruhi masa pengerjaan dan akan berpengaruh pula pada penentuan harga jual, demikian pula sebaliknya semaikn sederhana jenis barang yang dibuat dan rendahnya tingkat kesulitan dalam pembuatan maka semakin singkat waktu yang dibutuhkan dalam proses pengerjaan tenun songket dan harga yang ditawarkan juga tidak begitu tinggi.

Sebagai gambaran harga jual saat ini per helai kain dan selendang dari hasil kerajinan tenun songket Sambas dengan berbagai tingkat harga berkisar antara 300.000 sampai 2.500.000.

\section{Gambaran Pekerja Tenun Songket}

Usia produktif bagi pekerja tenun songket berkisar antara umur 15 tahun sampai 50 tahun (hasil observasi lapangan, 2016), lebih dari pada itu produktivitas pekerja akan menurun karena tenaga dan penglihatan mata pada umumnya sudah 
berkurang, sementara dalam pengerjaan tenun songet sangat dibutuhkan tenaga yang prima dan penglihatan mata yang normal.

Untuk saat ini perekrutan tenaga kerja baru banyak dilakukan dengan merekrut anak dari pekerja tenun, kelebihan pola perekturan seperti ini adalah kita tidak perlu menyediakan waktu dan tempat pelatihan khusus karena kesehariannya sudah dilatih oleh ibunya atau saudaranya yang sudah mahir menenun selain itu sikap mental dari pekerja baru yang direkrut dari anak seorang pekerja tenun lebih memiliki keyakinan yang kuat untuk pekerja sebagai penenun, beda halnya dengan cara perekrutan pekerja yang diambil dari calon pekerja yang tidak punya latar belakang keluarga penenun, relative lebih sulit untuk diajak bekerja sebagai penenun karena kurangnya keyakinan mereka terhadap usaha tenun akan bisa memenuhi kebutuhan ekonomi mereka, selain itu lebih lambat dalam menerima pelajaran menenun karena tidak pernah melihat pengerjaan menenun sebelumnya.

Saat ini jumlah perusahaan tenun songket sambas cukup banyak dan masing - masing perusahaan memiliki jumlah penenun yang bervariasi yaitu antara 5 - 40 pekerja / penenun.

\section{Pemasaran Tenun Songket Sambas}

Pemasaran memegang peranan yang cukup penting dalam keberlanjutan usaha tenun songket sambas. Adapun upaya pemasaran hasil kerajinan tenun songket Sambas dilakukan dengan beberapa cara diantaranya :

- Menawarkan langsung kepada konsumen dengan mendatangi langsung tempat pembeli maupun dengan meletak barang hasil kerajinan di toko atau galeri tenun songket yang berada di kediaman rumah pemilik usaha tenun songket.

- Upaya lain dalam pemasaran lewat ajang pameran baik di tingkat Kabupaten, Provinsi, Nasional maupun Internasional, kegiatan pameran yang diikuti tentunya atas kerja sama Pemerintah Daerah dengan pelaku usaha tenun songket, dalam ajang pameran yang diikuti, selain mempromosikan hasil kerajinan tenun songket juga bisa langsung menjual hasil kerajinan tenun songket ditempat pameran.

\section{KESIMPULAN DAN SARAN \\ Kesimpulan}

Dari penjelasan pada bab sebelumnya maka dapat ditarik kesimpulan bahwa :

1. Dilihat dari karakteristiknya, sebagian besar penenun berada pada usia produktif (15 - 69 tahun), tingkat pendidikan yang masih relative rendah, dan berasal dari keluarga yang kurang mampu. Pada umumnya mereka dari keluarga yang menggantungkan hidupnya pada sektor pertanian.

2. Potret industry tenun songket sambas masih merupakan warisan budaya sehingga belum dikelola secara optimal. Output yang dihasilkan relative rendah yaitu sekitar satu helai kain selama 21 - 30 hari dengan tingkat upah antara Rp 800.000 - Rp 1.200 .000 per bulan (angka ini dibawah upah minimum kabupaten). Selain itu untuk memproduksi kain tenun dibutuhkan modal kerja yang cukup besar (sekitar Rp 5.300.000,-) dengan harga jual produk antara Rp 300.000 - Rp 7.500.000 (tergantung jenis produk dan kualitas produk). Jumlah tenaga kerja setiap perusahaan 
berkisar sekitar 5 - 40 pekerja dan pemasarannya masih terkonsentrasi pada pasar lokal, meskipun ada pasar internasional akan tetapi relative terbatas.

\section{Saran}

Temuan dari pembahasan pada bab sebelumnya maka peneliti memberikan saran :

1. Diperlukan perhatikan dan pembinaan secara serius dan komprahensif untuk mengembangkan industri tenun oleh pemerintah kabupaten, pusat, provinsi maupun daerah.

2. Perlu strategi kerjasama dengan stakcholder antara pemerintah, LSM, lembaga adat, swasta dan perguruan tinggi untuk pengembangan industry tenun songket Sambas ini.

\section{DAFTAR PUSTAKA}

Alfian. 2012. Profil Tenun Sambas.

Alvin, Toffler. 1988. Gelombang Ketiga (Bagian Pertama). Pantja Simpati, Jakarta.

Ardinia. Dwi. 2015. Human Capital. Seberkas Coretan Kata. http://dwiardinia.blogspot.co.id/2015/05/human-capital-pengertianhuman-capital.html tanggal 3 Maret 2016

Badan Pusat Statistik Provinsi Kalimanatan Barat. 2014. Kalimantan Barat Dalam Angak 2014. Pontianak

Badan Pusat Statistik Kabupaten Sambas. 2014. Sambas Dalam Angak 2014. Sambas

Bank Dunia. 1990.

Dinas Kependudukan dan Pencatatan Sipil Kabupaten Sambas. 2013

Dessler. Gary, 2011. A Framework for Human Resource Management (7th Edition). Terjemahan Paramita Rahayu. Klaten : Intan Sejati.

Drucker, Peter F. 2010. Pengantar Manajemen. Pustaka Binaman. Jakarta.

Fontana, M.C. 2012. Corrosion Enginering Hand book. Mc Graw Hill Book Company. New York.

Gabriel Mirel M, Bogdan Ciubotaru. 2013. Advanced Network Programming Principles and Techniques. London. Springer - Verlag.

Idris, Fahmi. 2010. "Kebijakan dan Strategi Pengembangan Industri Nasional" http:/www.satgas.go.id. (16 Maret 2010)

Putra, Windhu. 2008. Ekonomi Industri. Bandung: Alfabeta

Rahmawati dan Amir. 2003. Studi Potensi Industri Kecil di Desa Tertinggal Dalam Rangka Pemberdayaan Pengusaha Kecil di Kabupaten Banyumas.Rachbini, D. J. 2001. Pembangunan Ekonomi dan Sumber Daya Manusia. Jakarta: PT Grasindo

Ruslan, Rosady. 2006. Metode Penelitian. Jakarta: PT Raja Grafindo Persada. Stuckey. 2003.

Yusriansyah. 2011. Karakteristik pengusaha industri keripik tempe di Kota Malang 